\title{
ANALYSIS OF EXPERT VALIDATION ON DEVELOPING FACTORS INFLUENCING CAREER CHOICE MALAYSIAN VOCATIONAL COLLEGE TEACHERS' MODEL
}

\author{
Abdul Mutalib M. R. ${ }^{1 *}$, Mahmud M. I. ${ }^{2}$, Mohd Affandi, H. ${ }^{3}$, Irawan $\mathrm{I}^{4}$, Che Rus R ${ }^{5}$ \\ ${ }^{1}$ Department of Engineering and Skills, Jerantut Community College, 27000 Jerantut, Malaysia, ${ }^{2}$ Department of \\ Community Well-being \& Education, Faculty of Education, 43600 Bangi, Malaysia, ${ }^{3}$ Centre of Engineering and Built \\ Environment Education Research (PeKA), Faculty of Engineering and Built Environment, 43600 Bangi, Malaysia, \\ ${ }^{4}$ Department of Built Environment, Faculty of Design \& Built Environment, First City University College, 47800 Petaling \\ Jaya, Malaysia. ${ }^{5}$ Department of Engineering Technology, Malaysia and Universiti Pendidikan Sultan Idris, Faculty of \\ Technical and Vocational Education, Tg. Malim, Malaysia. \\ Email: "redzwanmutalib@gmail.com
}

Article History: Received on $21^{\text {st }}$ August 2019, Revised on $29^{\text {th }}$ September 2019, Published on $06^{\text {th }}$ November 2019

\section{Abstract}

Purpose of study: The teaching profession is often seen as a non-rewarding career due to high burden duties that the teachers must endure. Consequently, many teachers lose interest in teaching, which resulted in a lack of job satisfaction. However, this profession has been chosen due to intrinsic, extrinsic and altruistic motivation. In view of this, there are some factors that are not explored in depth in a teaching career at Vocational Colleges.The purpose of this study is to explore Malaysian Vocational College teachers' career choice. The goals of this research are to discover factors that lead Malaysian Vocational College teachers to pursue teaching and to identify the sub-factors in preparing them to be vocational teachers.

Methodology: The development of the constructs Malaysian Vocational College teachers' career choice is based on 114 literature review articles. This goal is accomplished through 5 panels of experts consensus through the online questionnaires. Online questionnaires are chosen to conduct the survey because of its good review and user-friendliness. All levels of the agreement will be elevated by using the Fliess Kappa $(K)$ because more than 2 respondents. Fleiss Kappa is then used to evaluate the level of agreement between the raters.

Result: There are six major key factors found: family influence, socio-cultural influence, individual, situational and spiritual. There are 130 items developed and the overall finding $\mathrm{K}$ value is 0.55 . Nevertheless, the $\mathrm{K}$ value within six major key factors is 0.4 to 0.86 . The expert panels agree that this questionnaire might be acceptable with some improvement based on their additional comments in the online form. Based on this validation process, this questionnaire can be used in selecting the quality of Malaysian Vocational College teachers or TVET instructors. For the next step, this questionnaire will be conducted on 52 excellent teachers at Malaysian Vocational Colleges to understand in depth the key factors that significantly influence the decision of an individual to enter the vocational teaching profession in Malaysian Vocational Colleges.

Implications/Applications: In the future, the findings on this research will expose rich sources on the field of teaching and will be helpful to identify some high-quality TVET teachers in Malaysian Vocational College.

Keywords: Vocational Teachers, Career Choice, Malaysian Vocational College, Validation, Teaching profession.

\section{INTRODUCTION}

Education plays an important role in a country to grow economically or socially. Education provides knowledge based on economics emphasized fields, such as mathematics and science, information and communication technologies, basic knowledge, skills in literacy and the development of interpersonal skills. These skills and knowledge will equip learners to fulfill the needs of future professionals, decision-makers and trainers (Tomšik, 2016; Tomšik \& Gatial, 2018).

In Malaysia, teaching career is considered a mid-level profession under the other professional professions such as doctors, engineers, lawyers, and others (Azman, 2013). Nonetheless, teaching profession is still being chosen as one's career due to his or her intrinsic, extrinsic and altruistic motives, despite the challenges and underpaid wages. (Azman, 2013; Mogra, 2013; Wyatt-smith, 2017). Nevertheless, some teachers, which include vocational teachers, have opted for early resignation within three to five years of service as teachers (Esmali Bari, 2017; Ling, 2007).

The teaching profession is often seen as a non-rewarding career due to high burden duties that the teachers have to endure. Consequently, many teachers lose interest in teaching, which resulted in lack of job satisfaction (Butt, Mackenzie, \& Manning, 2010). Therefore, this study aims to validate a research instrument in determining factors influencing career choice Malaysian Vocational College teachers.

\section{Factors Influencing Vocational College Teachers Career Choice}

This section reports on the factors influencing teachers in choosing a teaching career, and in choosing vocational field as their teaching path. Based on 114 literature findings, six major key factors that influence vocational college teachers' career choice can be identified: family influence, socio-cultural influence, individual, situational and spiritual factors. 
The finding from the systematic review shown as in figure one below:

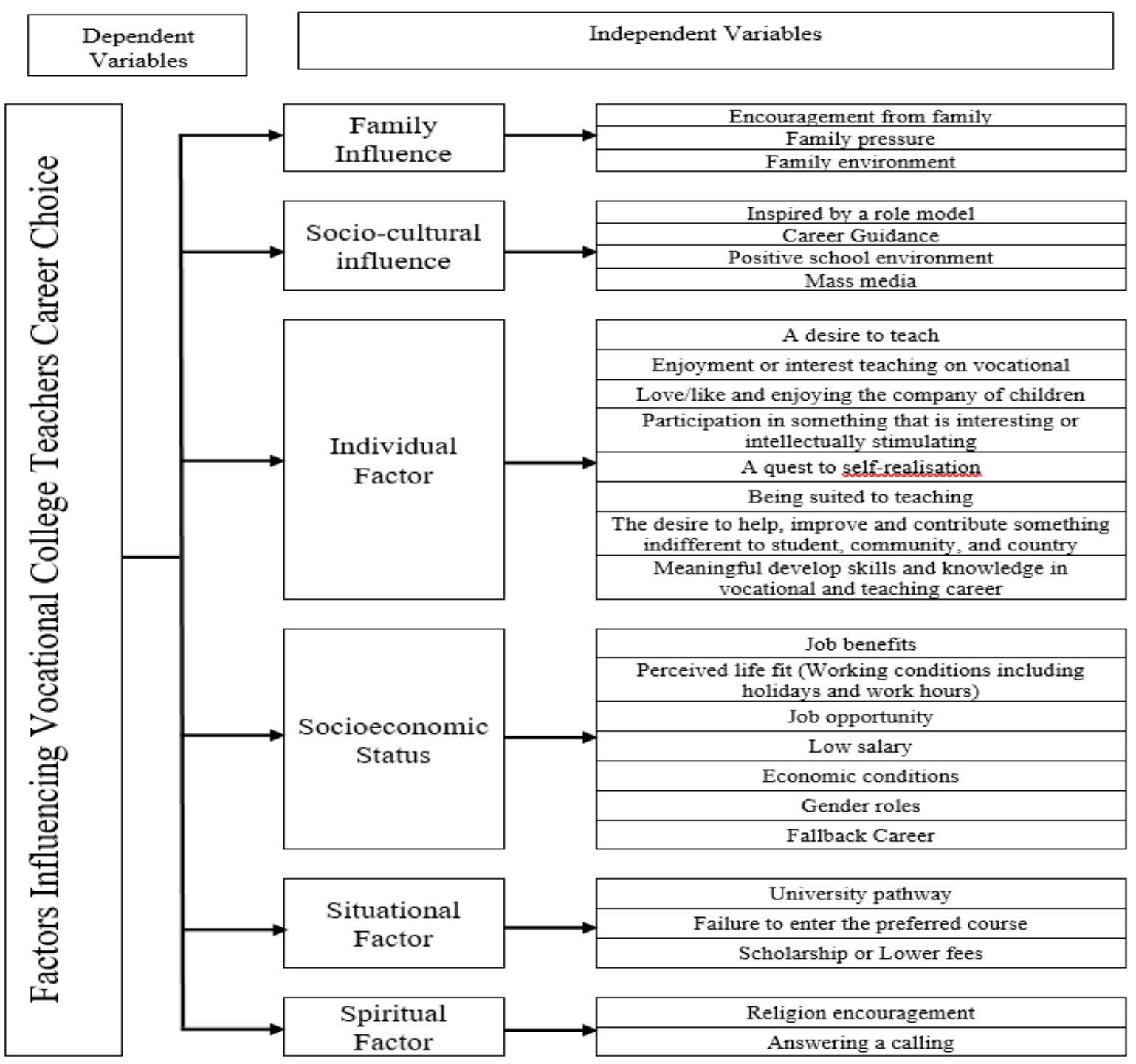

Figure 1: Overview of the factors influencing vocational college teachers' career choice

Based on the TVET teacher's career choice model, Evans (1997) argues that there are six factors that influence teachers' decisions in determining their career paths. One of the elements from this model suggests that there is an emotional element that involves teachers' fears. This element means about the teachers become fear to develop themselves in teaching career especially in administration jobs, teamwork and resource person (Evans, 1997; O'Neil et al., 1980).

This emotional element from Evans (1997) has removed because the analyzed from 114 research articles from 2008 till 2018 using metadata analysis not shown any construct related.Overall, this research is focusing on the usage of career choice theory in TVET among teachers or vocational instructors.

\section{METHODOLOGY/MATERIALS}

There are five expert panels who were selected and four of them are working as lecturers at Higher Education Institution, and one participant works as a Principal in a Vocational College. All participants answered an online survey through JotForm.com. This website is chosen to conduct the survey because of its good review and user-friendliness. The website's link for expert panels' validation process is https://form.jotform.me/81068578212459.

After the instrument validation, the survey design must be returned to the expert panels to be re-evaluated. The expert panels will give some feedback for improvement in the survey design. This second evaluation is based on convergent validity and discriminates validity (Meirte et al., 2017; Zinbarg et al., 2018). The Likert scales were applied for the validation process. 
Table1: Expert Validation Likert Scale

\begin{tabular}{lllll}
\hline $\mathbf{1}$ & $\mathbf{2}$ & $\mathbf{3}$ & $\mathbf{4}$ & $\mathbf{5}$ \\
\hline Very Disagree & $\longleftarrow$ & Very Agree
\end{tabular}

This research does not use center decision scale format answers in showing the level of agreement, such as "not sure" or "neutral". This is important to avoid the refusal of the expert panels in choosing the level of consensus (Nadler, Weston, \& Voyles, 2015; Widhiarso, 2012). Besides, the panels probably would choose "not sure" or "neutral" as an answer if they have lack of understanding of the questionnaire; thus affecting the result of the study (Nadler et al., 2015). Therefore, scale without center answer is better than the normal survey format answer scale (DeCastellarnau, 2018; Widhiarso, 2012).

All levels of the agreement will be elevated by using the Fliess Kappa (Cohen, 1977, 1988). Fliess Kappa was chosen as it can be applied to more than 2 respondents (Powers, 2012).

Table 2: Fleiss Kappa Agreement Scale (Landis \& Koch, 1977; Falotico \& Quatto, 2015)

\begin{tabular}{ll}
\hline Interpretation & Fliess Kappa Value (K) \\
\hline Poor agreement & Under 0 \\
\hline Slight agreement & $0.01-0.20$ \\
\hline Fair agreement & $0.21-0.40$ \\
\hline Moderate agreement & $0.41-0.60$ \\
\hline Substantial agreement & $0.61-0.80$ \\
\hline Almost perfect agreement & $0.81-1.00$ \\
\hline
\end{tabular}

After expert panels validate the content of the instrument, the researcher will discuss with the supervisors to ensure the validity of the survey design before moving to the next research phase. The grammar and sentence structures of the questionnaires will also be proofread to ensure respondents' understanding when they attempt the questionnaires (Rosnah, Noor Hassim, \& Shafizah, 2013).

\section{RESULTS AND FINDINGS}

The findings show that $K$ value is 0.55 and it is interpreted as moderate agreement. According to Howitt \& Cramer, (2011), 0.7 is considered as a high category. However, this moderate agreement result might be acceptable and can be proceeded to the next research phase (McHugh, 2012).

Table 3: Interpretation of Factors Influencing Vocational College Teachers' Career Choice on the panel of experts' reviews

\begin{tabular}{lll}
\hline $\begin{array}{l}\text { Factors Influencing Vocational College } \\
\text { Teachers Career Choice }\end{array}$ & Fliess Kappa Value $(\boldsymbol{K})$ & Interpretation \\
\hline Family Influences & 0.61 & Substantial agreement \\
\hline Socio-Cultural Factors & 0.40 & Fair agreement \\
\hline Individual Factors & 0.47 & Moderate agreement \\
\hline Socioeconomic Status Factors & 0.65 & Substantial agreement \\
\hline Situational Factors & 0.61 & Substantial agreement \\
\hline Spiritual Factors & 0.86 & Almost perfect agreement \\
\hline
\end{tabular}

Based on table 3, spiritual factors are the highest $K$ score value with 0.86 point interpretation as almost perfect agreement. The second highest score is socioeconomic status factors with $K$ score value, which is 0.65 . Furthermore, family influences and situational factors share the same $K$ score value, which is 0.61 . However, this interpretation allows for very little agreement among raters to be described as "substantial". The lowest agreement among the panel of experts is individual factors and socio-cultural factors. The $K$ score value for individual factors is 0.47 and 0.4 score value for socio-cultural factors.However, accepting 0.40 to 0.60 as "moderate", which can be implied as the lowest value (0.40), is adequate agreement.

Hence, every item can be filtered due refer to the $K$ value results. However, the instrument's content including grammar and sentence structures should be discussed among supervisors and panel of experts. This research has made corrections on 65 questionnaires from 130 questionnaires based on the panel of expert reviews. Finally, the panel of expert reviews and discussed among supervisors formulate 133 questionnaires as a next stage to explore Malaysian Vocational College teachers' career choice.

\section{IMPLICATION}

The purpose of this study is to explore Malaysian Vocational College teachers' career choice. The goals of this research are to discover factors that lead Malaysian Vocational College teachers to pursue teaching and to identify the sub-factors in 
preparing them to be vocational teachers. This goal is accomplished through 5 panels of experts. Therefore, this questionnaire is suggested for future research to understand in depth the key factors that significantly influence the decision of an individual to enter the vocational teaching profession in Malaysian Vocational College. Further validation using Rasch analysis, a sophisticated approach to questionnaire development using modern psychometric methods, are necessary to validate date using a confirmatory process.

\section{SUGGESTIONS}

In addition, this model can make an important contribution towards the career development theory, research methodology and TVET teachers training institutions. Moreover, this model will provide rich sources of exposure to the field of teaching to parents, vocational teachers, and guidance counselors to promote vocational teacher education programs to their children or student if they identify the interest in vocational teaching in the student. As for the impact for the community, this model will determine some high-quality vocational teachers in Malaysian vocational colleges or other TVET providers to choose teachers on vocational education.

\section{CONCLUSION}

This research has explained the procedure of getting construct validation by expert panels. This research intends to build an instrument to explore Malaysian Vocational College teachers' career choice. The quantitative data received in identifying the construct and item formation analyzed by using Fleiss Kappa analysis to identify and evaluate the level of agreement in each item in the list of dimension construct and also item. In the next stage, the findings from the acquired quantitative data from excellent teachers will be fully analyzed using the Rasch measurement model to identify the validity and credibility of instruments.

\section{ACKNOWLEDGMENTS}

This research work is supported by the Project Ministry of Finance through the Ministry of Education Malaysia (20150024-106-04-3) National Child Development Research Centre Sultan Idris Education University, 35900 Tanjung Malim, Malaysia.

\section{REFERENCES}

1. Azman, N. (2013). European Journal Of Teacher Education Choosing Teaching As A Career: Perspectives Of Male And Female Malaysian Student Teachers In Training, (November 2014), 37-41. https://doi.org/10.1080/02619768.2012.678483

2. Butt, G., Mackenzie, L., \& Manning, R. (2010). Influences on British South Asian women's Choice Of Teaching As A Career: " You' Re Either A Career Person Or A Family Person; Teaching Kind Of Fits In The Middle ," (January 2010), 37-41. https://doi.org/10.1080/00131910903519769

3. Cohen, J. (1977). Statistical Power Analysis for the Behavioural Sciences (Second Edition). New York: Academic Press.

4. Cohen, J. (1988). Statistical Power Analysis for the Behavioral Sciences (2nd Edition). New York: Lawrence Erlbaum Associates, Publishers.

5. DeCastellarnau, A. (2018). A Classification Of Response Scale Characteristics That Affect Data Quality: A Literature Review. Quality and Quantity, 52(4), 1523-1559. https://doi.org/10.1007/s11135-017-0533-4

6. Esmali Bari. (2017). Dasar Penempatan-Pertukaran, Kompetensi, Dan Tanggungan Tugas Dalam Perkhidmatan Guru. Thesis PhD Universiti Malaya, Kuala Lumpur.

7. Evans, J. L. (1997). Factors Influencing African Americans To Select Teaching Careers In Vocational Education And Experiences That Relate To Their Progress In Vocational Teacher Licensure Programs. Blacksburg, Virginia. Retrieved from https://vtechworks.lib.vt.edu/handle/10919/30570

8. Falotico, R \& Quatto, P. (2015). "Fleiss' Kappa statistic without paradoxes.” Qual. Quant. 49:463-470. https://doi.org/10.1007/s11135-014-0003-1

9. Howitt, D., \& Cramer, D. (2011). Introduction to Research Methods in Psychology Third Edition (3rd Edition). Essex, England: Pearson Education Limited.

10. Landis, J.R., \& Koch, G.G. (1977). The measurement of observer agreement for categorical data. Biometrics, 33 1, 159-74. https://doi.org/10.2307/2529310

11. Ling, W. Y. (2007). Kepuasan Kerja Guru-Guru Aliran Pendidikan Teknikal Dan Vokasional Di Sekolah-Sekolah Menengah Teknik Di Negeri Johor Darul Takzim. Thesis : Universiti Teknologi Malaysia.

12. McHugh, M. L. (2012). Lessons in biostatistics Interrater reliability: the kappa statistic. Biochemia Medica 2012 , 22(3), 276-282. https://doi.org/10.11613/BM.2012.031

13. Meirte, J., Van Daele, U., Maertens, K., Moortgat, P., Deleus, R., \& Van Loey, N. E. (2017). Convergent And Discriminant Validity Of Quality Of Life Measures Used In Burn Populations. Burns, 43(1), 84-92. https://doi.org/10.1016/j.burns.2016.07.001

14. Mogra, I. (2013). A Faith Dimension on the Landscape of Teachers : Muslim Teachers on Recruitment, Retention and Career Advancement, 38(7). https://doi.org/10.14221/ajte.2013v38n7.2 
15. Nadler, J. T., Weston, R., \& Voyles, E. C. (2015). Stuck in the middle: The use and interpretation of mid-points in items on questionnaires. Journal of General Psychology, 142(2), 71-89. https://doi.org/10.108 $0 / 00221309.2014 .994590$

16. O’Neil, J. M., \& et al. (1980). Factors, correlates, and problem areas affecting career decision making of a crosssectional sample of students. Journal of Counseling Psychology, 27(6), 571-580. https://doi.org/10.1037/00220167.27.6.571

17. Powers, D. M. W. (2012). The Problem with Kappa, 345-355.

18. Rosnah, I., Noor Hassim, I., \& Shafizah, A. S. (2013). A Systematic Translation And Cultural Adaptation Process For Three-Factor Eating Questionnaire (TFEQ-R21). Medical Journal of Malaysia, 68(5), 424-434.

19. Tomšik, R. (2016). Choosing Teaching as a Career: Importance of the Type of Motivation in Career Choices, TEM Journal-Technology Education Management Informatics, 5(3), 396-400. https://doi.org/10.18421/TEM5321

20. Tomšik, R., \& Gatial, V. (2018). Choosing Teaching As a Profession : Influence of Big Five Personality Traits on Fallback Career, Problem of Education in The 21st Century, 76(1), 100-108.

21. Widhiarso, W. (2012). Aplikasi teori respons butir untuk mengidentifikasi kecenderungan responden memilih opsi tengah pada skala psikologi. Manuskrip Publikasi 2012, Fakultas Psikologi Universitas Gadjah Mada, 7(1), 33-43.

22. Wyatt-smith, C. (2017). Why choose teaching? A Matter of Choice : Evidence from the Field.

23. Zinbarg, R. E., Pinsof, W., Quirk, K., Kendall, A., Goldsmith, J., Hardy, N., ... Latta, T. (2018). Testing The Convergent And Discriminant Validity Of The Systemic Therapy Inventory Of Change Initial Scales. Psychotherapy Research, 28(5), 734-749. https://doi.org/10.1080/10503307.2017.1325022 